\title{
Current rice farming, water resources and micro-irrigation
}

\author{
K. G. Mandal*, A. K. Thakur and S. K. Ambast \\ ICAR-Indian Institute of Water Management, Bhubaneswar 751 023, India
}

Rice is the staple food for half of the world's population, and rice farming is a livelihood for millions of farmers in Asia. In India, it provides an individual with $32 \%$ of the total calorie and $24 \%$ of the total protein daily. This crop is mostly grown in puddled soil by transplanting, and flood irrigation is practised by farmers. Water or irrigation input to transplanted rice typically ranges from 1000 to $2000 \mathrm{~mm}$ depending upon the growing season, climatic condition, soil type and hydrological conditions. Facing water scarcity and climate change, reducing water requirement of this crop is a challenge. Out of $\mathbf{4 2 . 7 5}$ million hectare ( $\mathrm{m}$ ha) rice area, only $25.12 \mathrm{~m}$ ha is under irrigation. Regarding water resources, depletion of groundwater is alarming in the north Indian states. On the other hand, it is under-utilized in eastern India. Microirrigation, i.e. sprinkler and drip methods have been used with the aim of minimizing water use and enhancing water use efficiency of rice. In addition, evidence-based scientific understandings on microirrigation for rice have been elucidated in this article. The potential of drip or sprinkler irrigation to rice on water saving as well as scientific insight and critical appraisal have been expounded on reasons of yield reduction. This comprehensive treatise would facilitate the formulation of strategies or policies on efficient management of water or irrigation for rice cultivation.

Keywords: Micro-irrigation, rice farming, water resources and availability, water use efficiency.

GLOBALly, rice is the most important crop. It provides staple food for more than 3.5 billion people, i.e. about half of the world's population ${ }^{1}$. Worldwide, this crop is grown on an area of 162.72 million hectare ( $\mathrm{m} \mathrm{ha}$ ) with an annual production of about 741.48 million tonnes (mt) in 2014 . Asia accounts for $88 \%$ of the world's area and $90.5 \%$ of the world's production ${ }^{2}$. According to an estimate $^{3}$, about $114 \mathrm{mt}$ of additional milled rice will be needed by 2035 to meet the global food demand. In India, rice is grown on $43.86 \mathrm{~m} \mathrm{ha}$, which is the largest area among all rice-growing countries, with paddy production of $157.2 \mathrm{mt}$ (refs 2, 4) (Figure 1). With a rapid-growing population, India's food demand is increasing over the years and this will continue in the future. On the other

*For correspondence. (e-mail: kgmandal@gmail.com) hand, per capita water availability per year is declining (Figure 2). Therefore, rice production needs to be enhanced using less water in the coming years.

Rice provides $688 \mathrm{kcal} /$ capita, i.e. $\sim 32 \%$ of total calorie intake per day and protein intake of $\sim 24 \%$ of the total per day in India ${ }^{5}$. Export-import trends showed that India had imported only 1323 tonnes of milled rice, whereas export was $11.3 \mathrm{mt}$ with an export value of 8205 million USD in 2013 (ref. 2). Moreover, rice farming is the livelihood of millions of farmers in India and other Asian countries. Therefore, sustaining and improving the production of rice is essential to meet the global demands as well as for food security in India.

\section{Water resources in India and rice irrigation}

It has been estimated that, after accounting for losses due to evaporation, the total average annual water availability in India is 1869 billion cubic metre (BCM). Due to hydrological characteristics and topographical constraints, utilizable water is only $1123 \mathrm{BCM}$ (690 BCM from surface, $433 \mathrm{BCM}$ from groundwater), which is just $28 \%$ of the water derived from precipitation. About $85 \%$ of water usage $(688 \mathrm{BCM})$ is being diverted for irrigation, which may increase to $1072 \mathrm{BCM}$ by 2050 (refs 6, 7). A major source of irrigation is groundwater. Annual groundwater recharge is about $433 \mathrm{BCM}$, of which $212.5 \mathrm{BCM}$ is used for irrigation and 18.1 $\mathrm{BCM}$ for domestic and industrial purposes $^{6,8}$. However, there are considerable spatial and temporal variations in the availability of water as in case of rainfall. Depletion of groundwater and limitation of surface water imply that not all of the net sown area is amenable to irrigation.

In India, net irrigated area is $66.1 \mathrm{~m}$ ha $(2012-13)$. Rice-irrigated area is only $25.12 \mathrm{~m}$ ha, which is $58 \%$ of the rice area of $42.75 \mathrm{~m}$ ha (Figure 1). With regard to different sources of irrigation, canal-irrigated area in the country has remained constant at $16.63 \mathrm{~m}$ ha for the last 20 years; tank irrigation has decreased $2.25 \mathrm{~m}$ ha; whereas tube-well irrigation is steadily increasing and has reached about $29.17 \mathrm{~m}$ ha; area under other wells has remained almost constant with an average of $11.91 \mathrm{~m}$ ha (2010$11)^{4}$. Indiscriminate use of groundwater irrigation has caused alarming depletion in the North Indian states such as Rajasthan, Punjab and Haryana; a reliable estimate 


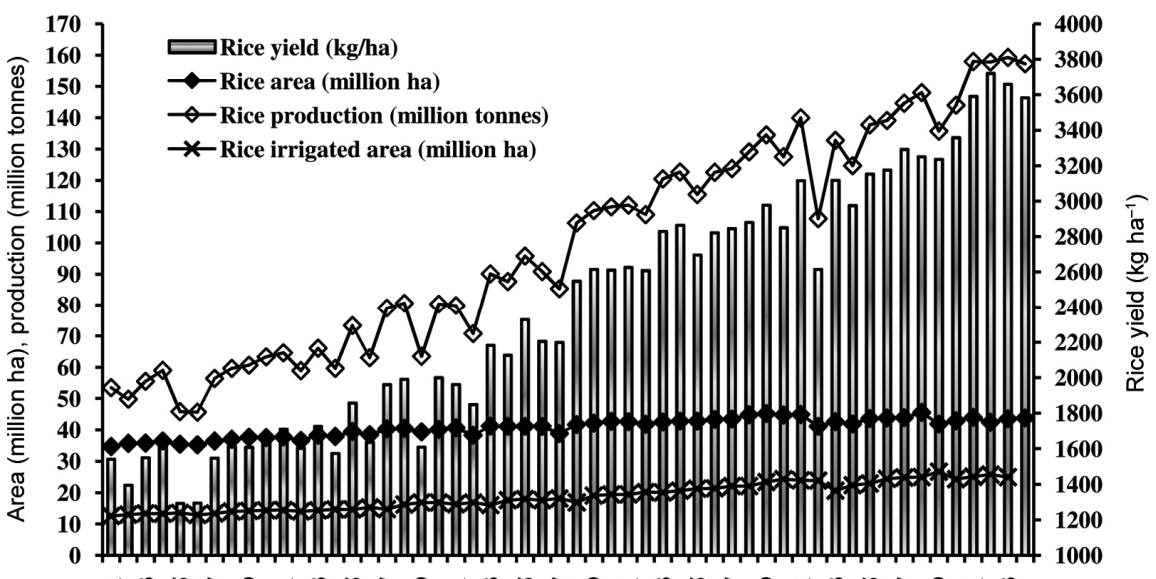

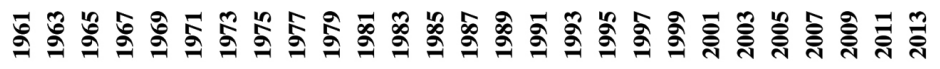

Figure 1. Trends in rice area, production, yield and irrigated area under this crop in India (1961-2014) ${ }^{4}$.

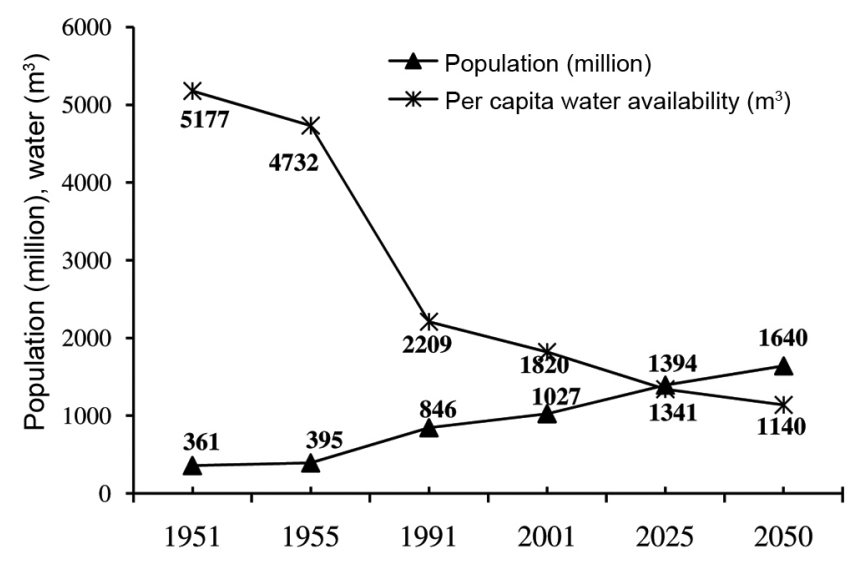

Figure 2. Trends and projection of population and per capita availability of water per year in India ${ }^{6}$.

showed that groundwater has depleted at the rate of $54 \pm 9 \mathrm{~km}^{3} /$ year between April 2002 and June 2008 (ref. $9)$; the depletion was equivalent to a net loss of $109 \mathrm{~km}^{3}$ of water from August 2002 to October 2008 (ref. 10). Hence, reducing overexploitation of groundwater is a challenge. On the other hand, groundwater development in the eastern Indian states, viz. Assam, Bihar, Chhattisgarh, Odisha and West Bengal remains low (22-43\%), which should be enhanced to the level of the country's average $(61 \%)^{8}$. Hence, there is a potential for use of drip or sprinkler irrigation to minimize water in North India and increase its use in eastern India.

\section{Rice cultivation and water usage}

Traditionally, rice is mostly grown by puddling the main field and transplanting seedlings into wet and saturated soil. The rice agro-ecosystems occupy areas in the eastern plains and plateaus, sub-Himalayan West Bengal and
Indo-Gangetic Plains (IGP), Tripura, Chhattisgarh, western and eastern coastal areas and Assam valley of India ${ }^{11}$. Water input to rice fields is practised for saturating land, facilitating puddling operation, maintenance of water layer, and to compensate for evaporation, transpiration, seepage and percolation losses. On average, 2500 litre of water is applied to produce $1 \mathrm{~kg}$ of rough rice ${ }^{12}$, which is 2-3 times more than other cereals ${ }^{13}$. This cultivation technique is labour-, water-, and energy-intensive and is becoming less profitable as these resources are becoming increasingly scarce ${ }^{3}$. However, most of the water applied during crop growth is not used directly for transpiration, and is therefore considered lost from the fields. In the Philippines, water use has been reported at 1300$1500 \mathrm{~mm}$ during the dry season and 1400-1900 $\mathrm{mm}$ in the wet season ${ }^{14}$. It was estimated that seasonal water input for typical puddled transplanted rice was $660-5280 \mathrm{~mm}$ depending on the growing season, climatic conditions, soil type and hydrological conditions, with 1000$2000 \mathrm{~mm}$ as a typical value in most cases ${ }^{15}$. In India, this value ranged from $1566 \mathrm{~mm}$ in clay loam soil to $2262 \mathrm{~mm}$ in sandy loam soil. In the IGP, it varied from $1144 \mathrm{~mm}$ in Bihar to $1560 \mathrm{~mm}$ in Haryana ${ }^{16}$. However, in recent years a major problem is the increasing water scarcity. In fact, water scarcity is threatening Asia's irrigated rice systems. In Asia, $17 \mathrm{~m}$ ha of irrigated rice area may experience physical water scarcity and $22 \mathrm{~m}$ ha may have economic water scarcity by 2025 (ref. 17). It implies that water needs to be used minimally through water-saving methods or techniques in the future.

\section{Water loss from rice fields and water-saving essentiality}

The loss components of a puddle rice field are evaporation, transpiration (combined as evapotranspiration, ET), 
percolation and seepage. So far as measurements are concerned, ET values are mostly reported. Typically, ET from rice fields is $4-5 \mathrm{~mm} \mathrm{~d}^{-1}$ during wet months and 6-7 $\mathrm{mm} \mathrm{d}^{-1}$ during dry months; this can be as high as 10 $11 \mathrm{~mm} \mathrm{~d}^{-1}$ in subtropical regions. It was estimated that about $\sim 30-40 \%$ of ET is due to evaporation ${ }^{14,18}$. Losses through seepage and percolation account for $1-5 \mathrm{~mm} \mathrm{~d}^{-1}$ in heavy clay soils and $25-30 \mathrm{~mm} \mathrm{~d}^{-1}$ in sandy and sandy loam soils ${ }^{14}$. The combined losses through seepage and percolation may be $25-50 \%$ of total water loss in heavy soils with shallow groundwater table $(20-50 \mathrm{~cm}$ depth); and $50-85 \%$ of total water loss in coarse textured soils with groundwater table $(1.5 \mathrm{~m} \text { depth or more })^{16,19,20}$. Losses through seepage and deep percolation from one field are recaptured and used in other fields downstream.

Therefore, more efficient management of water is needed for rice production. Several strategies are being pursued to reduce rice water requirements, such as saturated soil culture ${ }^{21}$, alternate wetting and drying ${ }^{18,22}$, system of rice intensification $(\mathrm{SRI})^{23-26}$ and aerobic rice ${ }^{27-29}$. In addition, an emerging water-saving technique is the use of micro-irrigation (sprinkler and drip irrigation). This is prevalent in fruit and vegetable cultivation; now researchers have started experiments to understand the feasibility of using micro-irrigation in rice. Hence, it is the need of the hour to elucidate existing information on the use of sprinkler and drip irrigation to rice for future strategies.

\section{System of rice intensification: a water-use efficient method}

SRI, which was developed in Madagascar, is now spreading to most rice-growing countries. It has become the method of choice for increasing rice production with reduced water demand and increased water productivity $^{23,26}$. Paddy fields are kept moist but not continuously flooded, either by saturated soil culture or by alternately wetting and drying. Under SRI, young seedlings are transplanted with wider spacing ${ }^{26}$, with active soil aeration using mechanical weeders and the application of available organic manure to stimulate beneficial soil $\operatorname{organisms}^{24,25}$. Yield increase $(25-50 \%$ or more) has been reported by researchers ${ }^{24-26}$. Such practices should be adapted to local conditions. Studies on the yield and water productivity performance of SRI should be systematically done using drip or sprinkler systems.

\section{Current scenario of micro-irrigation in India}

Micro-irrigation includes sprinkler and drip irrigation aiming at minimizing water use and enhancing water use efficiency (WUE) by crops. These may include joint application of fertilizers as in drip-fertigation. Pivot irrigation and/or irrigation using rain guns are also included under micro-irrigation. In India, area under micro-irrigation is only $7.7 \mathrm{~m}$ ha at present. Out of this, drip and sprinkler irrigation coverage is 3.37 and $4.36 \mathrm{~m}$ ha respectively, whereas its theoretical potential is estimated at around $69 \mathrm{~m}$ ha, and untapped potential is $61.8 \mathrm{~m}$ ha. There is large variation with respect to the adoption of drip or sprinkler irrigation in different regions of the country (Table 1). The top five states are Rajasthan, Maharashtra, Andhra Pradesh, Karnataka and Gujarat, that have adopted greater area compared with other states. In eastern India, Chhattisgarh is well ahead. Except Chhattisgarh, penetration (area under micro-irrigation divided by total net sown area in the state) of microirrigation is much lower in eastern India than the national value of $5.5 \%$. There is a huge scope of micro-irrigation in eastern India.

A survey-based study showed that there were benefits of micro-irrigation in crops other than rice; for example, $50-90 \%$ increase in WUE, 30.5\% savings in energy consumption, $28.5 \%$ savings in fertilizer consumption, $42.4 \%$ increase in fruit crops productivity, $52.7 \%$ in vegetables productivity, $31.9 \%$ savings in irrigation cost, $42 \%$ increase in farmers' income. An impact study report by the National Mission on Micro-irrigation, Government of India, clearly indicates that the overall efficiency of micro-irrigation (50-90\%) is much higher than surface irrigation (30-35\%). For rice crop, its application and adoption by farmers are not encouraging. Therefore, there is need to address problems in using micro-irrigation in rice and to make it adoptable for rice crop.

Table 1. Total micro-irrigation area coverage (except rice), and micro-irrigation penetration in India (as on 31 March 2015); penetration indicates area under micro-irrigation divided by net sown area ${ }^{4}$

\begin{tabular}{lrr}
\hline State & $\begin{array}{c}\text { Micro-irrigation } \\
\text { area (ha) }\end{array}$ & $\begin{array}{c}\text { Penetration } \\
(\%)\end{array}$ \\
\hline Haryana & 573,140 & 16.3 \\
Punjab & 42,966 & 1.0 \\
Rajasthan & $1,684,549$ & 9.3 \\
Madhya Pradesh & 352,117 & 2.3 \\
Sikkim & 8,313 & 10.8 \\
Mizoram & 2,152 & 2.2 \\
Nagaland & 5,205 & 1.4 \\
Chhattisgarh & 256,193 & 5.5 \\
Odisha & 100,578 & 2.3 \\
Bihar & 102,050 & 1.9 \\
Jharkhand & 16,222 & 1.5 \\
West Bengal & 51,180 & 1.0 \\
Andhra Pradesh & $1,163,306$ & 10.4 \\
Karnataka & 846,947 & 8.5 \\
Gujarat & 829,373 & 8.1 \\
Maharashtra & $1,271,126$ & 7.3 \\
Goa & 1,864 & 1.4 \\
Kerala & 29,464 & 1.4 \\
Tamil Nadu & 320,445 & 6.4 \\
All-India total & $7,775,314$ & 5.5 \\
\hline
\end{tabular}




\section{Evidence and scientific understanding on rice micro-irrigation}

Researchers have examined the use of sprinkler or pivot irrigation for rice since late 70 s and early 80 s. It has also been the goal of farmers and researchers in Zimbabwe ${ }^{30}$ and $\mathrm{USA}^{31,32}$. Earlier experiments on sprinkler irrigation were carried out at Arkansas, USA ${ }^{33,34}$ with positive findings on the feasibility of sprinkler irrigated rice and $50 \%$ of irrigation water saving. At Louisiana, USA, sprinklerirrigated rice produced fewer florets, fewer filled grains panicle $^{-1}$ than flood irrigation, whereas panicles $/ \mathrm{m}^{2}$ and specific grain weight were not significantly affected resulting into reduced grain yield by $25 \%$ (ref. 35). Reduced plant height was also reported in Texas, USA. At Arkansas, irrigation water applied to rice ranged from 610 to $1220 \mathrm{~mm}$ (ref. 36). Vories et al. ${ }^{37}$ reported 460 $1435 \mathrm{~mm}$ for 33 Arkansas rice fields, and Smith et al. ${ }^{38}$ reported 382-1034 $\mathrm{mm}$ in Mississippi, USA.

On a free-draining soil in New South Wales, Australia, line-source sprinkler system was examined with water amounting to $26-128 \%$ of Class-A pan evaporation. It was concluded that sprinkler irrigation was capable of much higher efficiency of water use than ponding to rice $^{32}$. However, plant production was not encouraging because of much shorter, more upright and robust stature plants in sprinkler-irrigated plots than those being continuously ponded. In central Sardinia rice area of Italy, in contrast, sprinkler irrigation clearly led to agronomic and environmental benefits, and economic advantages due to decreases in water requirement by $\sim 50 \%$ without decrease in rice yield ${ }^{39}$.

In Asia, researchers have used aerobic method ${ }^{14,16,29,40-44}$; a mixed response, i.e. similar or reducing yield was observed with concomitant saving of water. Under drip irrigation in Shanghai, China, drought-resistant varieties showed better yield capacity than puddled rice varieties; drip irrigation attained more than $95 \%$ of the yield level that was obtained under puddle condition ${ }^{45}$. Adaptation of rain-gun sprinkler has begun in Potohar plateau, Pakistan, to provide supplemental irrigation to dryland farming. However, wide-scale adoption was not reported in canalirrigated areas of the Indus Basin ${ }^{46}$.

A detailed elucidation has been made on the performance of rice crop with micro-irrigation across ricegrowing countries over the past several decades (Tables 2 and 3). Findings showed the potential for minimizing water usage in rice cultivation and improving WUE. However, reduced grain yield was also found due to water deficit in soil and sub-optimal physiological functioning of plants. Overall, depressing effect of lower water depth applied through sprinkler irrigation has been reported from USA and Australia ${ }^{35,47}$. More specifically, yield reduction due to water stress in sprinkler-irrigated rice had been reported in Texas, Arkansas and Louisiana in USA, as well as in Australia. Westcott and Vines ${ }^{35}$ reported yield losses up to $25-35 \%$ due to sprinkler irrigation. On a free-draining soil, Blackwell et al. ${ }^{32}$ found that yields obtained in sprinkler-irrigated rice were relatively lower, while grain yields from ponded plots were more than 7.0 tonne $\mathrm{ha}^{-1}$. Private organizations have also conducted research on rice by drips in various countries like Australia, Brazil, China, India, Japan, Spain, Thailand and USA.

\section{Water relation in plants and reasons for yield reduction}

Water deficit in soil, either during vegetative or reproductive stage of rice, affects rooting pattern and soil moisture extraction by plants. The effects may be leaf rolling, leaf elongation rate, leaf death, greater drying, decrease in relative water content (RWC), etc. Plants send signals for cessation of root growth under severe water stress; the effects may vary with cultivars. The physiological functions are also related, viz. root water extraction ${ }^{48}$, variation in canopy size ${ }^{49}$ and stomatal control of transpiration $^{50}$. Spikelet sterility increases and grain yield of rice drastically reduces due to water stress, especially if it occurs during flowering and grain-filling stages ${ }^{48}$. Due to moisture deficit in the soil, root length density, in general, is greater in the surface soil layers and declines with depth $^{51}$. Physiological functioning in plants, the rate of apical development, biomass production, spikelet number, panicle development, grain size and grain yield may be reduced to even their half, depending upon the severity and cultivar tolerance ${ }^{52}$. Hence, rice varieties having deep root systems would perform better under micro-irrigated condition.

There are chances that water stress may occur due to irrigation through drip or sprinklers, with accumulation of proline and abscisic acid (ABA) in rice plants. Proline accumulation is negatively correlated with midday leaf water potential and positively with leaf turgor and osmotic adjustment $^{53}$. Muirhead ${ }^{54}$ found a decrease in yield of sprinkler rice by $50 \%$ or more compared to continuous flooding. Blast disease of rice (Pyricularia grisea (Cooke) Sacc.) generally spreads through airborne spores. This has been the most devastating disease in North America. The severity of blast in a region, varies greatly each year due to weather conditions. Crop rotation is an important control practice because the fungus can survive on straw residue from the previous year. When highly susceptible cultivars are grown with flood irrigation, plant pathologists recommend deep flooding. Since sprinkler irrigation is not flooded, blast disease was common in many rice fields of mid-south United States in 2009.

In addition to the depressing factors, installation of sprinkler or drip system in larger areas would involve initial high costs, maintenance and preventive measures 
REVIEW ARTICLES

Table 2. Performance of rice to sprinkler irrigation, water usage and water use efficiency (WUE) and critical observation based on experimental studies by other researchers across rice-growing countries

\begin{tabular}{|c|c|c|c|}
\hline Location & Year of study, soil and methods & Yield performance, water usage and WUE; critical observations & Reference \\
\hline IRRI, Philippines & $\begin{array}{l}\text { 1976-82; silty clay-loam; dry season } \\
\text { experiment with var. 'IR 36' using } \\
\text { line-source sprinkler; irrigation at } \\
110 \% \text { of actual evapotranspiration } \\
\text { (ET) (ETa) as the wettest, while } \\
55 \% \text { less than maximum ET (ETm) } \\
\text { as the driest. }\end{array}$ & $\begin{array}{l}\text { Grain yield } 5.0 \text { tonne ha }{ }^{-1} \text { at } 110 \% \text { ETa, decreased to } 4.61 \text { tonne ha } \\
\text { at the moisture regime which was } 30 \% \text { less than ETm; further } \\
\text { reduced to } 0.94 \text { tonne ha }{ }^{-1} \text { at } 55 \% \text { less than ETm; strong linear } \\
\text { relationship between grain yield and ETa during flowering period } \\
\text { due to vapour pressure deficit (VPD), canopy temperature; soil } \\
\text { moisture at } 95 \% \text { and } 28.6 \% \text { of total crop extractable water showed } \\
\text { midday leaf water potential }-0.9 \text { and }-2.5 \mathrm{MPa} \text {, spikelet sterility } 20 \% \\
\text { and } 73 \% \text { respectively;leaf rolling in stressed level; exsertion of rice } \\
\text { panicle was sensitive to changes in leaf water potential; up to } 30 \% \\
\text { of spikelet sterility was associated with poor panicle exsertion. }\end{array}$ & $55-57$ \\
\hline
\end{tabular}

New South Wales, Early 80 s in Murrumbidgee irrigation Australia area, free-draining soil, line-source sprinkler operated at $26-28 \%$ of pan evaporation.

Grain yield $3.40 \mathrm{~kg} / \mathrm{mm}$ of water in sprinkler, $1.85 \mathrm{~kg} / \mathrm{mm}$ in ponded treatment; excellent weed control by herbicides applied through sprinklers.

Southeastern Queensland, Australia

Southeast Texas USA

Louisiana, USA

Portageville, Missouri Marsh Farm, USDAARS, USA
Mid-80s; clay soil; dry and wet conditions; short duration under upland with var 'Shinhakaburi', long duration upland with var. 'IR 43' and short duration lowland var. 'Labelle'; weekly sprinkler irrigation.

1982-84; clay soil; sprinkler irrigation; $100 \%, 50 \%$ and $25 \%$ of estimated ET

1983-84; clay soil; sprinkler irrigation thrice a week with $0.038 \mathrm{~m}$ water to maintain soil moisture tension above $-30 \mathrm{kPa}$

2009-10; sandy loam and silty loam; centre pivot irrigation $150 \mathrm{~m}$ long with 190-mm drill spacing for hybrid rice varieties. 'Templeton', 'Francis', 'Cocodrie', 'Taggart', 'Catahoula' under drill-seeded with

\section{Montanana, Zaragoza,} NE Spain

Kooshkak, Islamic Republic of Iran

2002-04; clay loam; sprinkler irrigation using rain-gun twice a week at $100-150 \%$ of ETc; $192-261 \%$ of ETc in the basin, with var. 'Super Basmati', puddle transplanted rice (June to October) lysimetric measurement of ET. Kamphiroozi', sprinkler irrigation at 1.0 pan evaporation (ETp) and 1.5 ETp compared to flooding and intermittent irrigation, $\mathrm{N}$ rate $32-152 \mathrm{~kg} \mathrm{ha}^{-1}$. $151 \mathrm{~kg} \mathrm{~N} \mathrm{ha}^{-1}$.

Grain yield 6.8 tonne ha $^{-1}$ in 'IR43', grain yield under dry conditions was $<10 \%$ of the corresponding yields in wet trial; low grain yield in other varieties due to inefficient conversion of solar radiation to dry matter; dry conditions signalled leaf rolling, delayed heading and affected grain setting.

Reduced yield by $20-28 \%$ in sprinkler due to weeds and disease infestation; water usage 931-1171 $\mathrm{mm}$ through sprinkler, and $1262-1742 \mathrm{~mm}$ through flood irrigation; sprinkler irrigation was not a viable alternative to conventional flood irrigation.

Grain yield 4.45-5.90 and 7.14-7.85 tonne $\mathrm{ha}^{-1}$ in sprinkler and flood irrigation respectively; decreased water use in sprinkler irrigation but reduced dry matter and florets panicle ${ }^{-1}$ due to increased sheath blight (Rhizoctonia solani)

Grain yield 8.20-8.31 tonne ha $^{-1}$ in 'Templeton' and 'Francis', less in other varieties; water usage $414 \mathrm{~mm}$ in 34 days, $503 \mathrm{~m}$ in 45 days; soil moisture tension $10-70 \mathrm{kPa}$ for $15 \mathrm{~cm}$ soil deptn and $30-50 \mathrm{kPa}$ for $30 \mathrm{~cm}$ soil depth; WUE 1.7 and $2.1 \mathrm{~kg} \mathrm{~m}^{-3}$ for flood and pivot irrigation respectively; more chances of Pyricularia grisea and Bipolaris oryzae, but less of Rhizoctonia solani in sprinkler-irrigated rice; disease outbreaks in centre pivot irrigation with inadequate weed control.

Crop height $1.55 \mathrm{~m}$ in $79-129$ days and $1.70 \mathrm{~m}$ in $113-147$ days; ET 750-800 $\mathrm{mm}$ in sprinkler-irrigated rice; crop coefficient $\left(K_{\mathrm{c}}\right)$ 1.06 and 1.03 during mid and late season respectively.

2000-01; silty loam; rice var. 'Champa- Grain yield 3.75-4.29 tonne ha ${ }^{-1}$ in sprinkler irrigation at 1.0-1.5 ETp with N $52 \mathrm{~kg} \mathrm{ha}^{-1} ; 5.96$ and 6.06 tonne ha $^{-1}$ in continuous and in intermittent flooding respectively; water usage 836-1373, 1778 and $2262 \mathrm{~mm}$ in sprinkler, intermittent and continuous flooding respectively; increased WUE by $20-60 \%$ in the former two methods than continuous flooding.

Grain yield 3.1-3.2 tonne ha ${ }^{-1}$ in sprinkler, and 3.1 tonne ha $^{-1}$ in basin irrigation, $\sim 18 \%$ more yield in sprinkler; water $5612-8417 \mathrm{~m}^{3} \mathrm{ha}^{-1}$ in sprinkler operating 39 times, and $10,795 \mathrm{~m}^{3} \mathrm{ha}^{-1}$ in basin irrigation operating 19 times; irrigation requirement could be as low as $26 \%$ with crop WUE $0.55 \mathrm{~kg} \mathrm{~m}^{-3}$ compared with $0.25 \mathrm{~kg} \mathrm{~m}^{-3}$ for basin 
REVIEW ARTICLES

Table 3. Performance of rice to drip and/or drip-fertigation, water usage and WUE, and critical observations based on experimental studies by other researchers across rice-growing countries

\begin{tabular}{|c|c|c|c|}
\hline Location & Year of study, soil and methods & Yield performance, water usage and WUE; critical observations & Reference \\
\hline IRRI, Philippines & $\begin{array}{l}\text { 1998-99; silty clay-loam, drip } 2-3 \\
\text { times a week, dry-seeded aerobic } \\
\text { variety double haploid lines crossed } \\
\text { from 'Azucena' and 'IR64'; weed } \\
\text { control by chemical and manual }\end{array}$ & $\begin{array}{l}\text { Grain yield } 0.8-3.2 \text { tonne } \mathrm{ha}^{-1} \text { in drip, and } 2.3 \text { tonne } \mathrm{ha}^{-1} \text { in } \\
\text { wet under upland condition, water regime at } 1.6 \text { times ET with soil } \\
\text { water potential above }-0.04 \mathrm{MPa} \text {; spikelet sterility } 30-78 \% \text { in drip, } \\
\text { relative water content (RWC) in leaves } 81-98 \% \text {. }\end{array}$ & 64 \\
\hline
\end{tabular}

Texas, USA

Virgin Island, USA

2001-06; drip irrigation with var. 'Cocodrie'.

2006-09; silty clay-loam; dry-season in aerobic condition, drip scheduled at $0.04 \mathrm{MPa}$

Xinjiang, China

2011-12; sandy loam; drip irrigation with plastic mulch in furrow, compared with no mulch furrow and conventional flooding; japonica var. 'Ninggeng28' and 'Xindao17'.

Xinjiang, China

2012 - up to seven seasons; sandy loam; drip with plastic mulch, compared with flood irrigation.

Ludhiana, Punjab, India

Madurai, Tamil

Nadu, India

Coimbatore, Tamil Nadu, India

Bhubaneswar, Odisha, India

Pradesh, India

Bhopal, Madhya Pradesh, India
2014-15; sandy clay; rainy season; sub-surface drip irrigation (SSDI) at $1.0 \mathrm{IW} / \mathrm{CPE}$, with $\mathrm{N}: \mathrm{P}: \mathrm{K}: \mathrm{Zn}$ at $120: 60: 40: 5 \mathrm{~kg} \mathrm{ha}^{-1}$.

2013-14; sandy loam, direct-seeded rice; rainy season; medium duration var. 'PR-115', drip at 1.5, 2.25 and 3.0 times pan evaporation (PE); $\mathrm{N} 120,150$ and $180 \mathrm{~kg} \mathrm{ha}^{-1}$.

2009-13; sandy loam; rainy and winter season; drip-fertigation at 100 and $150 \% \mathrm{PE}$; hybrid rice.

2011-12; red loamy/calcareous black, summer season, subsurface and surface drip-fertigation; conveyance through PVC pipe; NPK at $150: 50: 50 \mathrm{~kg} \mathrm{ha}^{-1}$.

2013; sandy loam; rainy season; short duration rice var. 'Khandagiri', puddled transplanted, supplemental irrigation through drip.

2013-14; heavy clay; rainy season; drip to SRI rice with $30 \times 30 \mathrm{~m}$ spacing; compared with conventional rice-continuous flooding, fertilizer $\mathrm{N}, \mathrm{P}_{2} \mathrm{O}_{5}$ and $\mathrm{K}_{2} \mathrm{O}$ at 150,100 and $120 \mathrm{~kg} \mathrm{ha}^{-1}$.
Similar grain yield and biomass production in drip and flood irrigation; $58 \%$ saving of irrigation water compared to flood irrigation.

No difference in crop growth; grain yield 2.88, 3.93 and 3.61 tonne ha ${ }^{-1}$ in 'Cybonnet', 'Bengal' and 'Neptune' respectively; higher yield in 'Cybonnet' and 'Neptune' under drip by 10-27\%, whereas higher yield in 'Bengal' and 'Taipei' by $6 \%$ in surface flooding.

Grain yield 5.78-5.90 tonne ha ${ }^{-1}$ with $1103-1121 \mathrm{~mm}$ water through drip, $8.32-8.58$ tonne $\mathrm{ha}^{-1}$ with $3420-3552 \mathrm{~mm}$ water in flooding; WUE 0.52 and $0.25 \mathrm{~kg} \mathrm{~m}^{-3}$ in drip and flooding respectively; supplemental irrigation $(30-60 \mathrm{~mm})$ up to three-leaf stage at soil water potential $-30 \mathrm{kPa}$ in $0-20 \mathrm{~cm}$ depth, irrigation with same amount during three-leaf stage to two-weeks before harvest at $-10 \mathrm{kPa}$ to avoid spikelet sterility.

Grain yield 10-12\% higher in drip and plastic mulch and $60 \%$ water saving; drip-plus-mulch-favoured conversion of soil $\mathrm{NH}_{4}^{+}$to $\mathrm{NO}_{3}^{-}$increased availability of $\mathrm{K}$ and $\mathrm{Zn}$, whereas decreased availability of $\mathrm{Mn}$, and negligible effect on $P$ availability.

Grain yield 7.34-8.01 and 6.63-7.60 tonne ha ${ }^{-1}$ with 860 and $1455 \mathrm{~mm}$ water in drip and flood irrigation respectively; water saving by $40-42 \%$; WUE $0.81-0.88$ and $0.42-0.52 \mathrm{~kg} \mathrm{~m}^{-3}$ in drip and flood irrigation respectively.

Grain yield 5.51-5.68 and 4.95-5.08 tonne $\mathrm{ha}^{-1}$ with 822-1027 and $591-757 \mathrm{~mm}$ water in drip at $150 \%$ and $100 \%$ PE respectively; WUE $6.93-8.25 \mathrm{~kg} \mathrm{ha}^{-1} \mathrm{~mm}^{-1}$ in drip fertigation; drip fertigation of $100 \%$ PE with $100 \%$ fertilizer along with azophosmet and humic acid increased yield.

Grain yield 3.74-4.25 tonne ha ${ }^{-1}$ in drip with $647.5-692.9 \mathrm{~mm}$ water, i.e. $8-17 \%$ higher yield and $7-27 \%$ increased water productivity compared to flood; suggested for large root system of rice to be suited for aerobic drip.

Grain yield 4.27, 4.39 and 3.92 tonne $\mathrm{ha}^{-1}$ in $100 \%, 125 \%$ and $75 \%$ of ETc in drip respectively, whereas it was 4.48 tonne ha $^{-1}$ with surface irrigation; drip (108-179 $\mathrm{mm})$ and surface irrigation $(5 \mathrm{~cm})$ after three days of drainage of standing water; surface irrigation (250 $\mathrm{mm}$ ) by hose pipe; WUE $0.604 \mathrm{~kg} \mathrm{~m}^{-3}$ in drip at $100 \%$ ETc and $0.432 \mathrm{~kg} \mathrm{~m}^{-3}$ in surface irrigation.

Grain yield 5.5 tonne ha ${ }^{-1}$ with $6316 \mathrm{~m}^{3}$ water (irrigation plus rainfall) in SSDI compared to 5.5 tonne ha ${ }^{-1}$ with $8420 \mathrm{~m}^{3}$ water with traditional flood irrigation; water productivity 0.88 and $0.59 \mathrm{~kg} \mathrm{~m}^{-3}$ respectively.

Grain yield 7.07 tonne $\mathrm{ha}^{-1}$ in system of rice intensification with $20 \mathrm{~cm}$ dripper spacing, highest water productivity of $0.90 \mathrm{~kg} \mathrm{~m}^{-3}$ and water-energy productivity of $7.85 \mathrm{~kg} \mathrm{kWh}^{-1}$; the corresponding values were 3.14 tonne $\mathrm{ha}^{-1}, 0.16 \mathrm{~kg} \mathrm{~m}^{-3}$ and $1.02 \mathrm{~kg} \mathrm{kWh}^{-1}$ respectively, in conventional rice with flood irrigation. 


\section{REVIEW ARTICLES}

against theft, etc. Moreover, it requires shifting to other fragmented plots for succeeding crops. All these factors possibly are not conducive to small and marginal rice farmers in India.

\section{Summary}

Rice is intimately associated with daily food consumption and livelihood of Asians. Rice farming needs more attention for increasing production as well as reducing water usage. Drip or sprinkler irrigation is a way to tackle water scarcity. The slogan should be 'more rice with less water'. In this study existing information has been reviewed and compiled on micro-irrigation technology for rice cultivation, and the emerging key points are summarized as follows:

- Sprinkler or drip irrigation needs to be scheduled for rice crop in the initial growth stages when soil water potential reaches about $-30 \mathrm{kPa}$ in $0-20 \mathrm{~cm}$ soil layer, i.e. around field capacity; supplemental irrigation (40$50 \mathrm{~mm}$ ) is required from three-leaf stage to threeweeks before harvesting. At the flowering stage, threshold soil water potential of $-10 \mathrm{kPa}$ may be considered appropriate to avoid spikelet sterility.

- Irrigation amount through drip or sprinkler should exceed crop evapotranspiration; about 750-1000 mm should be applied and frequency may be 1-3 times in a week depending upon the weather condition during crop-growing stage, rainfall, soil type, soil moisture depletion and varietal susceptibility to water stress.

- The variety should have a deeper root system, efficient in the conversion of solar radiation to dry matter, water stress-tolerant, suitable for growing under direct dry-seeding and aerobic method, and resistant to blast disease infestation. There are chances of occurrence of brown spot disease (Bipolaris oryzae), but less of sheath blight (Rhizoctonia solani).

- Application of effective fungicide is a must because rice blast may cause devastation and total crop failure. Similarly, effective weed management through manual, mechanical and/or application of herbicides, is required to curb weed menace.

- Efficacy of drip and/or drip-fertigation will be more if it is practised in combination with mulching. Plasticfilm mulching will effectively reduce evaporation loss of water and weed menace.

- There is a need for further research to eliminate negative and discouraging factors of micro-irrigation, and make this emerging technique suitable for rice and to minimize water use.

1. GRiSP (Global Rice Science Partnership). In Rice Almanac, International Rice Research Institute (IRRI), Los Baños, Philippines, 2013, 4th edn, p. 283.
2. FAO, FAOSTAT main database. Food and Agriculture Organization of the United Nations, 2017; www.fao.or/faostat/en/\#data/QC (accessed on 6 June 2017).

3. Kumar, V. and Ladha, J. K., Direct-seeding of rice: recent developments and future research needs. Adv. Agron., 2011, 111, $297-$ 413.

4. DES, Agricultural Statistics at a Glance, Directorate of Economics and Statistics, Department of Agriculture Cooperation and Farmers' Welfare, Ministry of Agriculture and Farmers' Welfare, Government of India (GoI), 2015, pp. 13-15; 83-84; 323-324; $340 ; 392-393$.

5. IRRI, World Rice Statistics Online Query Facility, 2017; http://ricestat.irri.org:8080/wrs (accessed on 19 June 2017).

6. CWC, Annual Report 2012-13, Central Water Commission, Ministry of Water Resources, GoI, 2013, pp. 1-14

7. CWC, Water and Related statistics 2010. Water Resources Information System Directorate, Information System Organization, Water Planning and Projects Wing, Central Water Commission, New Delhi, 2010, pp. xv-xiv.

8. GWYB, Ground Water Year Book 2013-14, Central Ground Water Board, Ministry of Water Resources, GoI, 2014, pp. 42-43.

9. Tiwari, V. M., Wahr, J. and Swenson, S., Dwindling groundwater resources in northern India, from satellite gravity observations. Geophys. Res. Lett., 2009, 36, L18401; doi:10.1029/2009 GL039401.

10. Rodell, M., Velicogna, I. and Famiglietti, J. S., Satellite-based estimates of groundwater depletion in India. Nature, 2009, 460, 999-1002.

11. Mandal, D. K., Mandal, C., Raja, P. and Goswami, S. N., Identification of suitable areas for aerobic rice cultivation in the humid tropics of eastern India. Curr. Sci., 2010, 99(2), 227-231.

12. Bouman, B. A. M., How much water does rice use? Rice Today, 2009, 8, 28-29.

13. Tuong, T. P., Bouman, B. A. M. and Mortimer, M., More rice, less water - integrated approaches for increasing water productivity in irrigated rice-based systems in Asia. Plant Prod. Sci., 2005, 8, 231-241.

14. Bouman, B. A. M., Peng, S., Castaneda, A. R. and Visperas, R. M., Yield and water use of irrigated tropical aerobic systems. Agric. Water Manage., 2005, 74, 87-105.

15. Tuong, T. P., Productive water use in rice production: opportunities and limitations. J. Crop Prod., 1999, 2, 241-264.

16. Choudhury, B. U., Bouman, B. A. M. and Singh, A. K., Yield and water productivity of rice-wheat on raised beds at New Delhi, India. Field Crops Res., 2007, 100, 229-239.

17. Tuong, T. P. and Bouman, B. A. M., Rice production in water scarce environments. In Water Productivity in Agriculture: Limits and Opportunities for Improvement (eds Kijne, J. W., Barker, R. and Molden, D.), CABI Publishing, Wallingford, UK, 2003, pp. 5367.

18. Tabbal, D. F., Bouman, B. A. M., Bhuiyan, S. I. Sibayan, E. B. and Sattar, M. A., On-farm strategies for reducing water input in irrigated rice; case studies in the Philippines. Agric. Water Manage, 2002, 56(2), 93-112.

19. Cabangon, R. J. et al., Effect of irrigation method and N-fertilizer management on rice yield, water productivity and nutrient-use efficiencies in typical lowland rice conditions in China. Paddy Water Environ., 2004, 2, 195-206.

20. Dong, B., Molden, D., Loeve, R., Li, Y. H., Chen, C. D. and Wang, J. Z., Farm level practices and water productivity in Zanghe irrigation system. Paddy Water Environ., 2004, 2, $217-$ 226.

21. Borell, A., Garside, A. and Shu, F. K., Improving efficiency of water for irrigated rice in a semi- arid tropical environment. Field Crops Res., 1997, 52, 231-248.

22. Li, Y. H., Research and practice of water-saving irrigation for rice in China. In Water-Saving Irrigation for Rice (eds Barker, R. Li, 
Y. and Tuong, T. P.), International Water Management Institute, Sri Lanka, 2001, pp. 135-144.

23. Stoop, W., Uphoff, N. and Kassam, A., A review of agricultura research issues raised by the system of rice intensification (SRI) from Madagascar: opportunities for improving farming systems for resource-poor farmers. Agric. Syst., 2002, 71, 249-274.

24. Thakur, A. K., Uphoff, N. and Edna, A., An assessment of physiological effects of system of rice intensification (SRI) practices compared with recommended rice cultivation practices in India. Exp. Agric., 2010, 46(1), 77-98.

25. Thakur, A. K., Rath, S. and Mandal, K. G., Differential responses of system of rice intensification (SRI) and conventional flooded rice management methods to applications of nitrogen fertilizer. Plant Soil, 2013, 370, 59-71.

26. Thakur, A. K., Rath, S., Roy Chowdhury, S. and Uphoff, N. Comparative performance of rice with system of rice intensification (SRI) and conventional management using different plant spacings. J. Agron. Crop Sci., 2010, 196(2), 146-159.

27. Bouman, B. A. M., Yang, X., Wang, H. Q., Wang, Z., Zhao. J. and Chen, B., Performance of aerobic rice varieties under irrigated conditions in North China. Field Crops Res., 2006, 97, 53-65.

28. Bouman, B. A. M., Feng, L., Tuong, T. P., Lu, G., Wang, H. Q. and Feng, Y., Exploring options to grow rice under water-short conditions in northern China using a modelling approach. II: quantifying yield, water balance components, and water productivity. Agric. Water Manage., 2007, 88(1/3), 23-33.

29. Mandal, K. G., Kundu, D. K., Thakur, A. K., Kannan, K., Brahmanand, P. S. and Kumar, A., Aerobic rice response to irrigation regimes and fertilizer nitrogen rates. J. Food, Agric. Environ., 2013, 11(3\&4), 1148-1153.

30. Oosterhuis, D. M., Nitrogen studies on rice grown under sprinkler irrigation in the southeastern low filed of Rhodesia. Rhodesia Agric. J., 1978, 75, 5

31. Talbert, R. E., Akkari, K. H., Gilmore, J. T. and Ferguson, J. A., Update on sprinkler- irrigated rice production. In Proceedings of the 19th Rice Technical Working Group, Hot Springs, Arkansas, USA, 23-25 February 1982, pp. 87-88.

32. Blackwell, J., Meyer, W. S. and Smith, R. C. G., Growth and yield of rice under sprinkler irrigation on a free-draining soil. Aust. J. Exp. Agric., 1985, 25(3), 636-641.

33. Ferguson, J. A. and Gilmore, J. T., Centre pivot sprinkler irrigation of rice. Arkansas Farm Res., March-April 1977, pp. 12-20.

34. Ferguson, J. A. and Gilmore, J. T., Water and nitrogen relations of sprinkler irrigated rice. Arkansas Farm Res., May-June 1978, pp. 22-30.

35. Westcott, M. P. and Vines, K. W., A comparison of sprinkler and flood irrigation for rice. Agron. J., 1986, 78, 637-640.

36. Tacker, P., Vories, E., Wilson Jr, C. and Slaton, N., Water management. In Rice Production Handbook (ed. Slaton, N. A.), University of Arkansas, 2001, Chap. 9, pp. 75-86.

37. Vories, E. D., Tacker, P. L. and Hogan., R., Multiple inlet approach to reduce water requirements for rice production. Appl. Eng. Agric., 2005, 21(4), 611-616.

38. Smith, M. C. et al., Water use estimates for various rice production systems in Mississippi and Arkansas. Irrig. Sci., 2006, 25(2), 141-147.

39. Spanu, A., Murtas, A. and Ballone, F., Water use and crop coefficients in sprinkler irrigated rice. Ital. J. Agron., 2009, 2, 47-58.

40. Belder, P. et al., Effect of water-saving irrigation on rice yield and water use in typical lowland conditions in Asia. Agric. Water Manage., 2004, 65, 193-210.

41. Belder, P., Bouman, B. A. M., Spiertz, J. H. J., Peng, S., Castaneda, A. R. and Visperas, R. M., Crop performance, nitrogen and water use in flooded and aerobic rice. Plant Soil, 2005, 273, 167182.

42. Lampayan, R. M., Bouman, B. A. M., Faronilo, J. E., Soriano, J. B., de Dios, J. L., Espiritu, A. J. and Thant, K., Yield of aerobic rice in rainfed lowlands of the Philippines as affected by nitrogen management and row spacing. Field Crops Res., 2009, 116, 165-174.

43. Nie, L., Peng, S., Bouman, B. A. M., Huang, J., Cui, K., Visperas, R. M. and Xiang, J. G., Alleviating soil sickness caused by aerobic monocropping: responses of aerobic rice to nutrient supply. Field Crops Res., 2008, 107, 129-136.

44. Peng, S., Bouman, B. A. M., Visperas, R. M., Castañeda, A., Nie, L. and Park, H. K., Comparison between aerobic and flooded rice in the tropics: agronomic performance in an eight-season experiment. Field Crops Res., 2006, 96, 252-259.

45. Adekoya, M. A. et al., Agronomic and ecological evaluation on growing water-saving and drought-resistant rice (Oryza sativa L.) through drip irrigation. J. Agric. Sci., Can., 2014, 6(5), 110-119.

46. Kahlown, M. A., Raoof, A., Zubair, M. and Kemper, W. D., Water use efficiency and economic feasibility of growing rice and wheat with sprinkler irrigation in the Indus Basin of Pakistan. Agric. Water Manage., 2007, 87(3), 292-298.

47. Inthapan, P. and Fukai, S., Growth and yield of rice cultivars under sprinkler irrigation in southeastern Queensland. 2. Comparison with maize and grain sorghum under wet and dry conditions. Aust. J. Exp. Agric., 1988, 28(2), 243-248.

48. Lilley, J. M. and Fukai, S., Effect of timing and severity of water deficit on four diverse rice cultivars. II. Physiological responses to soil water deficit. Field Crops Res., 1994, 37(3), 215-223.

49. Mitchell, J. H., Siamhan, D., Wamala, M. H., Risimeri, J. B., Chinyamakobvu, E., Henderson, S. A. and Fukai, S., The use of seedling leaf death score for evaluation of drought resistance of rice. Field Crops Res., 1998, 55, 129-139.

50. Dingkuhn, M., Cruz, R. T., O'Toole, J. C. and Doerffling, K., Net photosynthesis, water use efficiency, leaf water potential and leaf rolling as affected by water deficit in tropical upland rice. Aust. J. Agric. Res., 1989, 40, 1171-1181.

51. Lilley, J. M. and Fukai, S., Effect of timing and severity of water deficit on four diverse rice cultivars. I. Rooting pattern and soil water extraction. Field Crops Res., 1994, 37(3), 205-213.

52. Lilley, J. M. and Fukai, S., Effect of timing and severity of water deficit on four diverse rice cultivars III. Phenological development, crop growth and grain yield. Field Crops Res., 1994, 37(3), 225-234.

53. Dingkuhn, M., Cruz, R. T., O’Toole, J. C., Turner, N. C. and Doerffling, K., Response of seven diverse rice cultivars to water deficits. III. Accumulation of abscisic acid and proline in relation to leaf water potential and osmotic adjustment. Field Crops Res., 1991, 27, 103-117.

54. Muirhead, W. A., Blackwell, J., Humphreys, E. and White, R. J. G., The growth and nitrogen economy of rice under sprinkler and flood irrigation in southeast Australia. 1. Crop response and $\mathrm{N}$ uptake. Irrig. Sci, 1989, 10,183-199.

55. Cruz, R. T. and O'Toole, J. C., Dryland rice response to an irrigation gradient at flowering stage. Agron. J., 1984, 76, 178-183.

56. O'Toole, J. C. and Moya, T. B., Genotypic variation in maintenance of leaf water potential in rice. Crop Sci., 1978, 18, 873-876.

57. Novero, R. P., O’Toole, J. C.. Cruz, R. T. and Garrity, D. P., Leaf water potential, crop growth response, and microclimate of dryland rice under line source sprinkler irrigation. Agric. For. Meteorol., 1985, 35(1-4), 71-82.

58. Fukai, S. and Inthapan, P., Growth and yield of rice cultivars under sprinkler irrigation in southeastern Queensland. 3. Water extraction and plant water relations - comparison with maize and grain sorghum. Aust. J. Exp. Agric., 1988, 28(2), 249-252.

59. McCauley, G. N., Sprinkler vs flood irrigation in traditional rice production regions of southeast Texas. Agron. J., 1990, 82, 677683.

60. Vories, E. D., McCarty, M., Stevens, G., Tacker, P. and Haidar, S., Comparison of flooded and sprinkler irrigated rice production. ASABE Paper No. IRR10-9851, American Society of Agricultural and Biological Engineers, Michigan, USA, 2010; www.asabe.org 


\section{REVIEW ARTICLES}

61. Vories, E. D., Stevens, W. E., Tacker, P. L., Griffin, T. W. and Counce, P. A., Rice production with center pivot irrigation. Appl. Eng. Agric., 2013, 29(1), 51-60.

62. Moratiel, R. and Martı'nez-Cob, A., Evapotranspiration and crop coefficients of rice (Oryza sativa L.) under sprinkler irrigation in a semiarid climate determined by the surface renewal method. Irrig. Sci., 2013, 31, 411-422.

63. Pirmoradian, N., Sepaskhan, A. R. and Maftoun, M., Effects of water-saving irrigation and nitrogen fertilization on yield and yield components of rice (Oryza sativa L.). Plant Prod. Sci., 2004, 7(3), 337-346.

64. Lafitte, R., Relationship between leaf relative water content during reproductive stage water deficit and grain formation in rice. Field Crops Res., 2002, 76, 165-174.

65. Medley, J. and Wilson, L. T., The use of sub-surface drip irrigation for rice. In Proceeding of the 10th National Convention System on Cotton and Rice Conference, Texas, USA, 2005, pp. 33-34.

66. Zimmerman, T., Evaluation of irrigation systems for rice production on St. Croix, USVI. Virgin Islands Water Resource Research Institute, University of Virgin Island, St. Thomas, 2011, p. 8.

67. He, H. et al., Rice performance and water use efficiency under plastic mulching with drip irrigation. PLOS ONE, 2013, 8(12), e83103; doi:10.1371/journal.pone.0083103.

68. Zhu, Q. C., Wei, C. Z., Li, M. N., Zhu, J. L. and Wang, J., Nutrient availability in the rhizosphere of rice grown with plastic film mulch and drip irrigation. J. Soil Sci. Plant Nutr., 2013, 13(4), 943-953.

69. Sharda, R., Mahajan, G., Siag, M., Singh, A. and Chauhan, B. S., Performance of drip irrigated dry seeded rice (Oryza sativa L.) in south Asia. Paddy Water Environ., 2017, 15, 93-100.
70. Govindan, R. and Grace, T. M., Influence of drip fertigation on growth and yield of rice varieties (Oryza sativa L.). Madras Agric. J., 2012, 99(4/6), 244-247.

71. Vanitha, K. and Mohandass, S., Effect of humic acid on plant growth characters and grain yield of drip fertigated aerobic rice (Oryza sativa L.). Bioscan, 2014, 9(1), 45-50.

72. Vanitha, K. and Mohandass, S., Drip fertigation could improve source-sink relationship of aerobic rice (Oryza sativa L.). Afr. J. Agric. Res., 2014, 9(2), 294-301.

73. Parthasarathi, T., Mohandass, S., Senthilvel, S. and Vered, E., Effect of drip irrigation systems on yield of aerobic rice. Environ. Ecol., 2013, 31(4A), 1826-1829.

74. Parthasarathi, T., Vanitha, K., Mohandass, S. and Vered, E., Importance of large root system on increasing yield in drip irrigated aerobic rice. Bioscan, 2014, 9(4), 1541-1544.

75. Panigrahi, P., Rautaray, S. K., Panda, R. K., Thakur, A. K. and Raichaudhuri, S., Response of rain-fed rice to supplemental irrigation with drip and surface irrigation methods in eastern India. Int. J. Trop. Agric., 2015, 33(2), 971-975.

76. AICRP-IWM, Annual Report 2015-16, All India Coordinated Research Project on Irrigation Water Management (ICAR), Rajmata Vijayaraje Scindiya Krishi Vishwa Vidyalaya, Zonal Agricultural Research Station, Morena, 2016, pp. 47-52.

77. Rao, K. V. R., Gangwar, S., Keshri, R., Chourasia, L., Bajpai, A. and Soni, K., Effects of drip irrigation system for enhancing rice (Oryza sativa L.) yield under system of rice intensification management. Appl. Ecol. Environ. Res., 2017, 15(4), 487-495.

Received 29 August 2017; revised accepted 1 December 2018

doi: $10.18520 / \mathrm{cs} /$ v116/i4/568-576 